\title{
DRY BIOMASS DISTRIBUTION IN A CERRADO SENSU STRICTO SITE IN CENTRAL BRAZIL ${ }^{1}$
}

\author{
Ailton Teixeira do Vale ${ }^{2}$ e Jeanine Maria Felfili ${ }^{2}$
}

\begin{abstract}
The Cerrado has been the main source of firewood and charcoal in Brazil, but despite being one of the hot spots for conservation of the world's biodiversity, neither plantations of native species nor sustainable management has been adopted in the region. The aim of this work was to investigate the biomass distribution and the potential for energy production of the cerrado species. The study was conducted in a cerrado sensu stricto site at the Água Limpa Farm (15 56' 14' S and 47 46' $08^{\circ}$ ' W) in the Cerrado Biosphere Reserve. An area of $63.54 \mathrm{ha}$ was divided in 20 x 50m plots and, a random sample consisting of ten of these plots, representing $1.56 \%$ of the study-site, was assessed. All woody individuals from $5 \mathrm{~cm}$ diameter at 30 $\mathrm{cm}$ above ground level were identified and measured. Each individual was felled, the twigs thinner than $3 \mathrm{~cm}$ were discarded while the larger branches and the trunks, both with bark, were weighted separately. After that, $2.5 \mathrm{~cm}$ transverse sections of the trunk with bark were taken at $0,25,50,75$ and $100 \%$ of the length. A similar sample was also taken at the base of each branch. A total of 47 species in 35 genera and 24 families were found, with an average density of 673 individuals per ha. The diameter distribution showed a reversed$\mathrm{J}$ shape with $67 \%$ of the individuals up to $13 \mathrm{~cm}$, while the maximum diameter was $32.30 \mathrm{~cm}$. Seven species represented $72 \%$ of the total biomass. In general, the species with higher production per tree were among those with higher production per ha. This content was distributed by diameter classes, reaching a maximum of $2.5 \mathrm{ton} / \mathrm{ha}$ between 9 to $13 \mathrm{~cm}$ and then, decreasing to 0.96 ton/ha between 29 to $33 \mathrm{~cm}$ diameter. Carbon sequestering was $6.2 \mathrm{ton} / \mathrm{ha}$ (until the actual stage of cerrado) based on an average $50 \%$ carbon content in the dry matter. The heat combustion of the wood varied from $18,903 \mathrm{kj} / \mathrm{kg}$ to $20,888 \mathrm{kj} / \mathrm{kg}$ with an average of $19,942 \mathrm{kj} / \mathrm{kg}$. The smaller diameter classes fix more carbon due to the large number of small plants per ha. But, for a species that reached larger dimensions and contained individuals in all diameter classes, Vochysia thyrsoidea, one can verify an increase in carbon fixation from $1.41 \mathrm{~kg} / \mathrm{ha}$ in the first class (5 to $9 \mathrm{~cm})$ to $138,3 \mathrm{~kg} / \mathrm{ha}$ in the last $(25$ to $33 \mathrm{~cm})$. That indicates that it is possible to select species that reach larger size with a higher capacity of carbon accumulation per plant. The species that reached larger dimensions, with a production per tree above average and had high calorific power values were Dalbergia miscolobium, Pterodon pubescens and Sclerolobium paniculatum. These species have potential for use in fuelwood plantations and sustainable management.
\end{abstract}

Keywords: Cerrado, savanna, wood calorific power, biomass and carbon sequestering.

\section{DISTRIBUIÇÃO DE BIOMASSA SECA EM UM SÍTIO DE CERRADO SENSU STRICTO NO BRASIL CENTRAL}

RESUMO - O Cerrado foi a principal fonte de lenha e carvão no Brasil, mas, apesar de ser uma das áreas mais conhecidas para conservação da biodiversidade no mundo, ainda não foram feitas plantações de espécies nativas e nem manejo sustentável foi adotado na região. O objetivo deste trabalho foi investigar a distribuição de biomassa e o potencial para produção de energia das espécies de cerrado. O estudo foi realizado em

\footnotetext{
${ }^{1}$ Recebido em 27.02.2003 e aceito para publicação em 10.08.2005.

${ }^{2}$ Departamento de Engenharia Florestal da Universidade de Brasília. 70910-900 Brasília-DF.
} 
um sítio de cerrado sensu stricto na Fazenda Água Limpa (15'56'14 ' S e 4746'08 “' W), na Reserva de Biosfera do Cerrado. Uma área de 63.54 ha foi dividida em lotes de $20 x 50 m$, e uma amostra casualizada que consiste em 10 destes lotes, representando 1,56\% do local de estudo, foi avaliada. Todos os indivíduos lenhosos de $5 \mathrm{~cm}$ diâmetro a $30 \mathrm{~cm}$ acima do solo foram identificados e medidos. Cada indivíduo foi cortado, sendo os ramos mais finos que $3 \mathrm{~cm}$ descartados e os ramos e troncos maiores, ambos com casca, foram pesados separadamente. Em seguida, seções transversais de 2,5 cm foram removidas do tronco com casca a 0, 25, 50, 75 e 100\% do comprimento. Uma amostra semelhante também foi removida na base de cada ramo. Foi encontrado um total de 47 espécies de 35 gêneros e 24 famílias, com uma densidade média de 673 indivíduos por ha. A distribuição de diâmetro apresentou uma forma J-invertida com $67 \%$ dos indivíduos até $13 \mathrm{~cm}$, enquanto o diâmetro máximo foi de 32,30 cm. Sete espécies representaram $72 \%$ da biomassa total. Em geral, as espécies com produção mais alta por árvore estavam entre as de produção mais alta por ha. Esse conteúdo se distribuiu por classes de diâmetro, alcançando um máximo de 2.5 t/ha entre 9 e $13 \mathrm{~cm}$ e, então, diminuindo para 0,96 t/ha entre 29 e $33 \mathrm{~cm}$ de diâmetro. O seqüestro de carbono foi de 6,2 t/ha (até a fase atual de cerrado), baseado em uma média de conteúdo de $50 \%$ de carbono na matéria seca. O calor de combustão da madeira variou de 18,903 kj/kg a 20,888 kj/kg, com uma média de 19,942 $\mathrm{kj} / \mathrm{kg}$. As classes de menor diâmetro fixam mais carbono devido ao grande número de plantas pequenas por ha. Mas, para uma espécies que alcançou dimensões maiores e continha indivíduos em todas as classes de diâmetro, Vochysia thyrsoidea, pode-se verificar um aumento em fixação de carbono de 1,41 kg/ha na primeira classe (5 a $9 \mathrm{~cm}$ ) para 138,3 kg/ha na última (25 a $33 \mathrm{~cm}$ ). Isso indica que é possível selecionar espécies que alcançam tamanho maior com uma capacidade mais alta de acumulação de carbono por planta. As espécies que alcançaram dimensões maiores, com uma produção por árvore acima da média, e tiveram valores altos de poder calorífico foram Dalbergia miscolobium, Pterodon pubescens e Sclerolobium paniculatum. Essas espécies têm potencial para uso em plantações de combustível vegetal e manejo sustentável.

Palavras-chaves: Cerrado, savana, poder calorífico da madeira, biomassa e seqüestro de carbono.

\section{INTRODUCTION}

Several reneawable sources of energy have been studied as alternatives to fossil fuel, such as solar, wind, tidal and nuclear. Biomass stands out as the most versatile amongst these sources especially due to the well-developed energy conversion technologies and the availability of raw material (GRASSI e PALZ, 1998).

The biomass in Brazil contributed $19 \%$ of all primary energy consumed in 1999 and firewood represented $9 \%$ of that figure totalling $6.9 \times 10^{7}$ tons of wood burned in households (BRASIL, 2000). The native vegetation contributed a total of 70 million tons of the wood consumed for energy of which ca. 21 million were used in households serving about ten million with an average utilization of $22 \mathrm{~kg} /$ household/day. Rural people, especially those on low income are the main users of firewood.

The Brazilian cerrado was recently listed as one of the 25 hot spots for conservation of biodiversity, being amongst the most rich and endangered ecosystems of the world (MITTERMEYER et al., 1999). The biome contains a mosaic of savanna vegetation, gallery forests, and seasonal forests on limestone outcrops with over
6,000 vascular plants (MENDONÇA et al., 1998). It covers around two million ha but is being rapidly depleted of its natural vegetation. Around $60 \%$ of the cerrado has already been converted to large scale agriculture, cattle ranging, dams and urban sites (MITTERMYER et al., 1999). Until recently, extensive areas were cleared to supply charcoal for steel industries, which were then, used for agriculture. However, with the opening of the national markets to mineral coal from Eastern Europe, wood is now mostly used for domestic purposes, pottery, bricks and other small industries.

Tree planting on degraded land, and forest management supply charcoal by, therefore, avoiding new clearings in the remaining fragments. However, little is known on the biomass production and calorific power of the cerrado species. Calorific power is the quantity of heat liberated by the combustion of a unity of mass of a body. When the combustion happens at a constant volume and the water is produced during the condensation process, it is called superior calorific power (SCP) (DOAT, 1977). Heat combustion at $0 \%$ humidity varies from $14,651 \mathrm{kj} /$ $\mathrm{kg}$ to $20,930 \mathrm{kj} / \mathrm{kg}$ (BRITO, 1986).

R. Árvore, Viçosa-MG, v.29, n.5, p.661-669, 2005 
Basal area is lower in the woody component of the cerrado sensu stricto, ranging from 8 to $12 \mathrm{~m}^{2} \mathrm{ha}^{-1}$ (FELFILI et al., 1994, 1997), compared to the values found in Amazonian forests (PIRES and PRANCE, 1997) and gallery forests in central Brazil (FELFILI et al., 1994; FELFILI, 1995), of around 20 to $30 \mathrm{~m}^{2} \mathrm{ha}^{-1}$. Cerrado biomass is also low at 21.4ton ha ${ }^{-1}$ (SILVA, 1990) compared to Amazonian forests, which range from 97.5 ton ha-1 to 254.6ton ha $^{-1}$ (KRINGE et al, 1995; RUGANI et al., 1997).

Silva (1990) studied biomass and nutrient partitioning in the aerial parts including trunk, branches, leaves, flowers and fruits of 35 woody species of the Brazilian cerrado. $\mathrm{He}$ found an average of 0.62 ton $\mathrm{ha}^{-1}$ per species, varying from Byrsonima crassa with 0.64ton ha ${ }^{-1}$ to Sclerolobium paniculatum with 5.22ton ha-1 (HARIDASAN 2000). Few species reach more than $10 \mathrm{~cm}$ diameter in the cerrado sensu stricto (FELFILI and SILVA JÚNIOR, 1988; SILVA JÚNIOR and SILVA, 1988; NASCIMENTO and SADDI, 1992) and one could expect that some would be hardwoods with high calorific power reaching dimensions large enough to be used for charcoal.

The knowledge of the biomass accumulation, the dimensions of the aerial parts and the heart combustion of cerrado woody species can be used, with others characteristics (basic density, moisture, growth rate, etc) to select species for firewood and charcoal plantations and for reclaiming of degraded land by small farmers that could earn marginal revenues. It could also help the assessment of carbon emissions from the frequent burning of the cerrado vegetation.

The objective of this work was to determine the dry biomass by diameter classes and the calorific power of the species occurring in a cerrado sensu stricto site.

\section{MATERIALAND METHODS}

The study-site was a cerrado sensu stricto site at the University of Brasília Research Station in the Água Limpa Farm (15 56'14' S and 4746 '08' W) in the Federal District, in the nuclear zone of the Cerrado Biosphere Reserve in Brazil. The climate is Aw by Köppen's classification with an average precipitation of 1,600 mm (NIMER, 1989) and average altitude of $1,100 \mathrm{~m}$.

An area of 63.54ha was divided in $20 \times 50 \mathrm{~m}$ plots, a random sample consisting of ten of these plots, representing $1.56 \%$ of the study-site area, was assessed. All woody individuals from $5 \mathrm{~cm}$ diameter at $30 \mathrm{~cm}$ above ground (d) were identified and had their height and diameter measured according to the methodology adopted by Felfili and Silva Júnior (1993) for this physiognomy.

Seven diameter classes were found, ranging from 5 to $33 \mathrm{~cm}$. This amplitude and class interval is within the range to that found in other cerrado sites (FELFILI and SILVA JÚNIOR, 1988; SILVA JÚNIOR and SILVA, 1988; NASCIMENTO and SADDI, 1992).

Three individuals per diameter class per species were randomly selected and, each individual was logged at the ground level. The twigs smaller than $3 \mathrm{~cm}$ diameter were discarded while the larger branches and the trunks, both with bark, were weighted separately in a scale of $150 \mathrm{~kg}$ maximum capacity. After that, $2.5 \mathrm{~cm}$ transverse sections of the trunk with bark were taken at 0,25 , 50,75 and $100 \%$ of the trunk length. A similar sample was also taken at the base of each branch. In multitrunk trees, one was randomly selected for sampling. These transverse sections were tagged, put in plastic bags and sent to a Laboratory.

The moisture contents and the relation between the wood and the bark, was determined in laboratory just after the trees were cut. The fresh mass in the field was calculated by multiplying the fresh mass of wood and bark samples by the percentage of total wood and bark. Based on the moisture contents the total dry mass per tree was estimated per diameter classes.

The total values of energetic biomass were obtained from the trunk and the branches equal or larger than $3 \mathrm{~cm}$ diameter, that is, those branches that could be used for firewood.

The superior calorific power of the wood and the bark was obtained according to ABNT NBR 8633 procedure and the operation manual of the calorimeter PARR 1201 (ABNT, 1984).

\section{RESULTS AND DISCUSSION}

\subsection{Community richness and structure}

There was a total of 47 species in 35 genera in 24 families (Table 1). The average density was 673 individuals per ha.

Diameter distribution showed a reversed-J shape with $67 \%$ of the individuals up to $13 \mathrm{~cm}$ while the maximum diameter was $32.3 \mathrm{~cm}$, see Figure 1. The heights varied from $1 \mathrm{~m}$ to $13 \mathrm{~m}$ with most individuals up to $5 \mathrm{~m}$, see Figure 2 .

R. Árvore, Viçosa-MG, v.29, n.5, p.661-669, 2005 
Table 1 - Woody species with diameter from $5 \mathrm{~cm}$ at $30 \mathrm{~cm}$ above the ground level in the cerrado sensu stricto in the Água Limpa Farm, University of Brasília, Brasília-DF

Tabela 1 - Espécies lenhosas com diâmetro a partir de $5 \mathrm{~cm}$ acima do solo, em cerrado sensu stricto na Fazenda água Limpa, Universidade de Brasília, Brasília-DF

\begin{tabular}{|c|c|c|}
\hline Species & Family & Common Name \\
\hline Acosmium dasycarpum (Vog.) Yakovl. & Leg. Papilionoideae & Amargozinho \\
\hline Aspidosperma macrocarpon Mart. & Apocynaceae & Bolsinha \\
\hline Aspidosperma tomentosum Mart. & Apocynaceae & Guatambu \\
\hline Byrsonima coccolobaefolia H.B. \& K. & Malpighiaceae & Murici-vermelho \\
\hline Byrsonima crassa Nied. & Malpighiaceae & Murici \\
\hline Byrsonima verbascifolia (L.) Rich. ex A. L. Juss. & Malpighiaceae & Murici \\
\hline Blepharocalix salicifolius (H. B. \& K.) Berg & Myrtaceae & Maria-preta \\
\hline Caryocar brasiliense Camp. & Caryocaraceae & Pequi \\
\hline Connarus suberosus Planch. & Connaraceae & Coração-de-negro \\
\hline Dalbergia miscolobium Benth. & Leg. Papilionoideae & Jacarandá-do-cerrado \\
\hline Davilla elliptica St. Hil. & Dilleniaceae & Lixeirinha \\
\hline Dimorphandra mollis Benth. & Leg. Mimosoideae & Faveira \\
\hline Enterolobium gummiferum (Mart.) Macb. & Leg. Mimosoideae & Orelha-de-negro \\
\hline Eremanthus glomerulatus Less. & Compositae & \\
\hline Eriotheca gracilipes (K. Schum.) A. Robyns & Bombacaceae & Paineira \\
\hline Eriotheca pubescens (Mart. \& Zucc.) Schott. \& Endl & Bombacaceae & Paineira-do-cerrado \\
\hline Erythroxylum deciduum St. Hil. & Erythroxylaceae & Fruto-de-passarinho \\
\hline Erythroxylum suberosum St. Hil. & Erythroxylaceae & Muchiba \\
\hline Erythroxylum tortuosum Mart. & Erythroxylaceae & Muchiba-comprida \\
\hline Guapira noxia (Netto) Lund & Nyctaginaceae & \\
\hline Hymenaea stigonocarpa Mart. ex Hayne & Leg. Caesalpinoideae & Jatobá-do-cerrado \\
\hline Kielmeyera coriacea (Spreng.) Mart. var. coriacea & Guttiferae & Pau-santo \\
\hline Kielmeyera speciosa St. Hil. & Guttiferae & Pau-santo \\
\hline Lafoensia pacari St. Hil. & Lythraceae & Mangaba-brava \\
\hline Miconia ferruginata DC. & Melastomataceae & Lacre \\
\hline Miconia pohliana Cogn. & Melastomataceae & Lacre \\
\hline Myrsine guianensis (Aubl.) Kuntz & Myrsinaceae & \\
\hline Ouratea hexasperma (St. Hil.) Baill. & Ochnaceae & Cabelo-de-negro \\
\hline Palicourea rigida Kunth & Rubiaceae & Bate-caixa \\
\hline Pouteria ramiflora (Mart.) Radlk. & Sapotaceae & Grão-de-galo \\
\hline Piptocarpha rotundifolia (Less.) Baker & Compositae & Coração-de-negro \\
\hline Psidium warmingianum Kiaersk. & Myrtaceae & Araçá \\
\hline Pterodon pubescens (Benth.) Benth. & Leg. Papilionoideae & Sucupira-branca \\
\hline Qualea grandiflora Mart. & Vochysiaceae & Pau-terra-folha-grande \\
\hline Qualea multiflora Mart. & Vochysiaceae & Pau-terra-liso \\
\hline Qualea parviflora Mart. & Vochysiaceae & Pau-terra-roxo \\
\hline Rourea induta Planch & Connaraceae & \\
\hline Schefflera (Didymopanax) macrocarpa (Seem.) D.C. Frodin & Araliaceae & Mandiocão-do-cerrado \\
\hline Sclerolobium paniculatum Vog. Var. subvelutinum Benth. & Leg. Caesalpinoideae & Carvoeiro \\
\hline Strychnos pseudoquina St. Hil. & Loganiaceae & Quina-do-cerrado \\
\hline Stryphnodendron adstringens (Mart.) Cov. & Leg. Mimosoideae & Barbatimão \\
\hline Styrax ferrugineus Nees \& Mart. & Styracaceae & Laranjeira-do-cerrado \\
\hline Symplocos rhamnifolia A. DC. & Symplocaceae & \\
\hline Tabebuia ochracea (Cham.) Standl. & Bignoniaceae & Ipê \\
\hline Tabebuia serratifolia (Vah1.) Nicholson & Bignoniaceae & Ipê \\
\hline Vochysia elliptica Mart. & Vochysiaceae & Pau-doce \\
\hline Vochysia rufa Mart. & Vochysiaceae & \\
\hline Vochysia thyrsoidea Pohl. & Vochysiaceae & Gomeira \\
\hline
\end{tabular}

R. Árvore, Viçosa-MG, v.29, n.5, p.661-669, 2005 


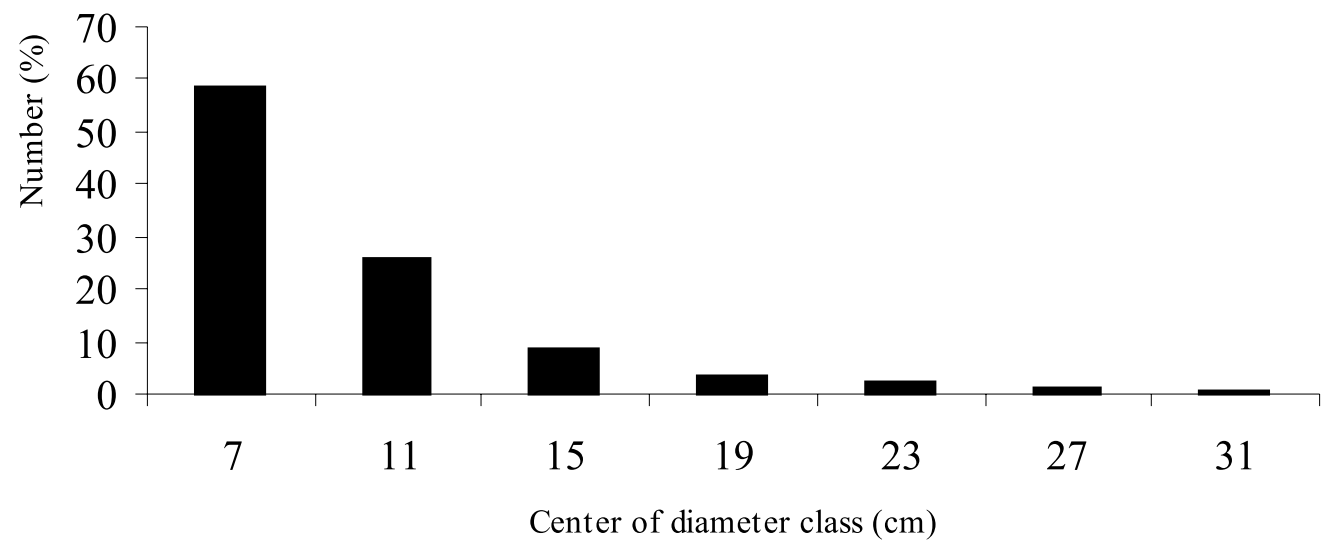

Figure 1 - Number of individuals (\%) per diameter classes per ha in the cerrado s.s. in the Água Limpa Farm, University of Brasília, Brasília-DF.

Figura 1 - Número de indivíduos (\%) por classe de diâmetro por ha em cerrado s.s. na Fazenda Água Limpa, Universidade de Brasília, Brasília-DF.

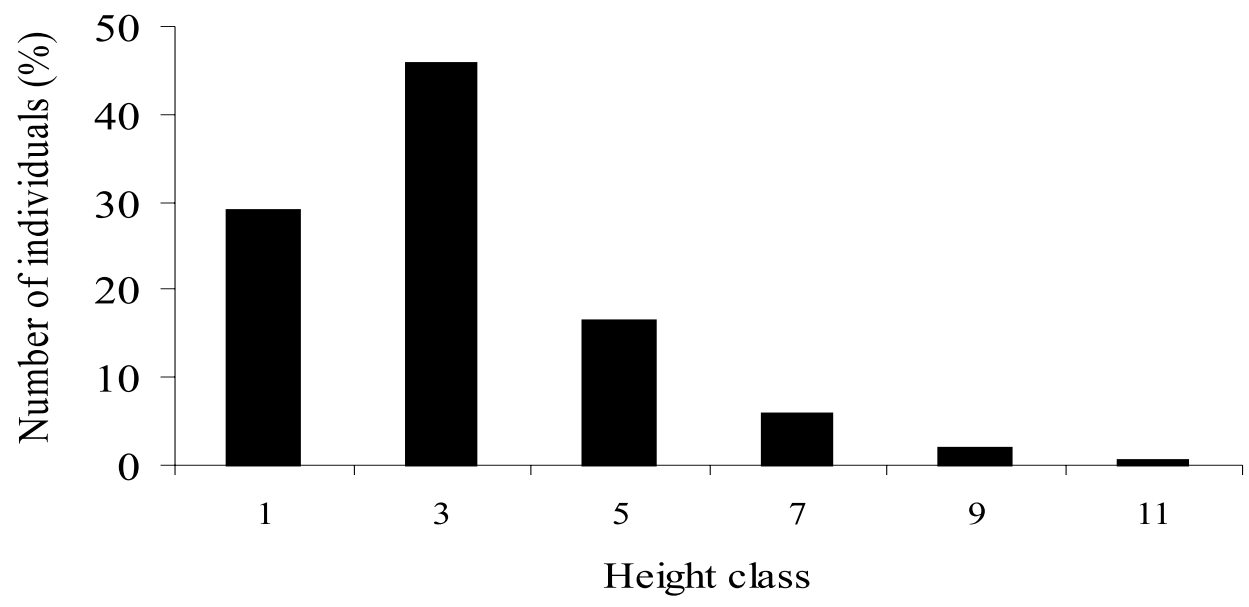

Figure 2 - Number of individuals (\%) by height class per ha in cerrado s.s. in the Água Limpa Farm, University of Brasília$\mathrm{DF}$.

Figura 2 - Número de indivíduos (\%) por classe de altura por ha em cerrado s.s. na Fazenda Água Limpa, Universidade de Brasília, Brasília-DF.

\subsection{Dry Biomass production}

Total dry biomass was 12.4 ton $\mathrm{ha}^{-1}$ with an average per species of $264 \mathrm{~kg} \mathrm{ha}^{-1}$ and 11 species had a total above average production. The highest production per species was $2,886 \mathrm{~kg} \mathrm{ha}^{-1}$ for Sclerolobium paniculatum. The production (Table 2) increased from the first diameter class ( 5 to $9 \mathrm{~cm}$ ) with $1,783 \mathrm{~kg} \mathrm{ha}^{-1}$ to the following ( 9 to $13 \mathrm{~cm}$ ) with $2,557 \mathrm{~kg} \mathrm{ha}^{-1}$ and then, came a smooth decreasing tendency till the last class ( 29 to $33 \mathrm{~cm}$ ) with $963 \mathrm{~kg} \mathrm{ha}^{-1}$. Total dry biomass $(\mathrm{kg}$ per tree) increased with diameter in contrast with number of trees (Figure 3) that decreased sharply. A large number of the species did not reach large diameters, and their trees are small with a low biomass, on average of $18.4 \mathrm{~kg}$ tree $^{-1}$.

R. Árvore, Viçosa-MG, v.29, n.5, p.661-669, 2005 


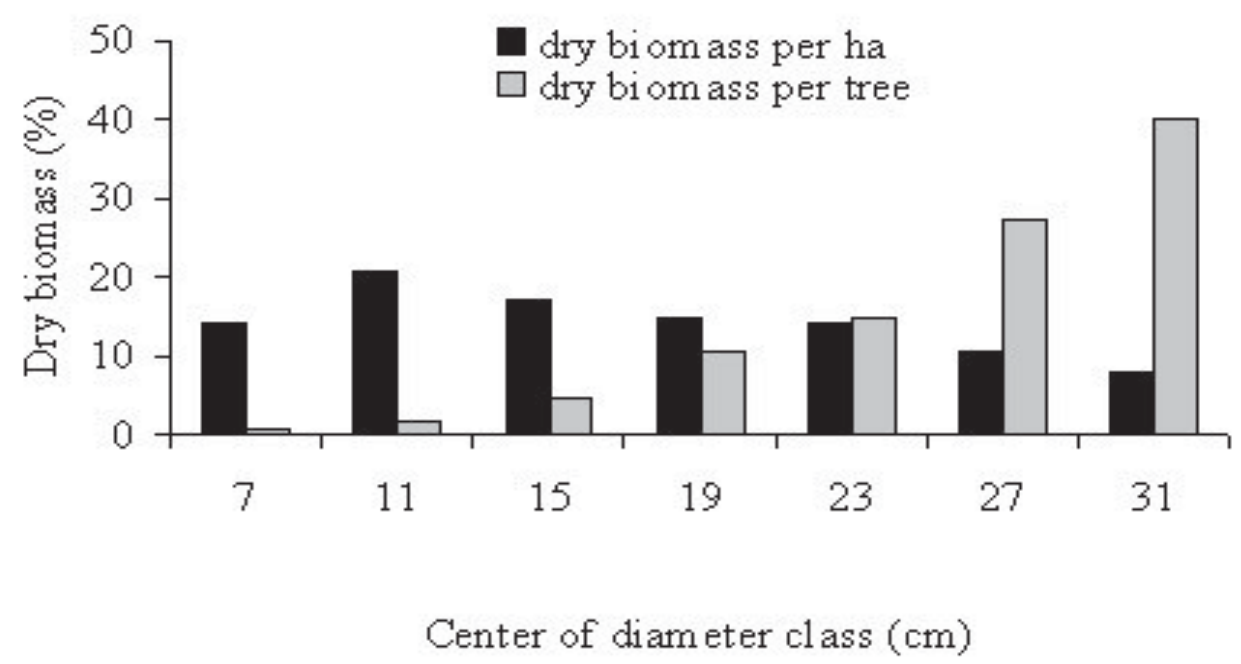

Figure 3 - Dry biomass (\%) per ha and per individual per diameter class in the cerrado s.s. in the Água Limpa Farm, University of Brasília, Brasília-DF.

Figura 3 - Biomassa seca (\%) por ha por classe de diâmetro em cerrado s.s. na Fazenda Água Limpa, Universidade de Brasília, Brasília-DF.

The few species that reached large diameters (above $13 \mathrm{~cm}$ ), with biomass values per tree above average were: Blepharocalix salicifolius, Caryocar brasiliense, Hymenaea stigonocarpa, Pterodon pubescens, Qualea grandiflora, Qualea parviflora, Sclerolobium paniculatum and Vochysia thyrsoidea. Those seven species represented $72 \%$ of the total biomass.

In general, the species with higher production per tree were among those with higher production per ha. However, Ouratea hexasperma, with low production per tree, showed a high production per ha due to a high density per ha.

\subsection{Heat combustion}

The heat combustion of the wood varied from $19,903 \mathrm{kj}$ $\mathrm{kg}^{-1}$ for Blepharocalix salicifolius to $20,888 \mathrm{kj} \mathrm{kg}^{-1}$ for Acosmium dasycarpum. The average for this cerrado was $19,942 \mathrm{kj} \mathrm{kg}^{-1}$. Species in the same genus had similar values of SCP (Table 2), except for Erythroxylum, with $18,837 \mathrm{kj} \mathrm{kg}^{-1}$ for E. suberosum, $19,414 \mathrm{kj} \mathrm{kg}^{-1}$ for $E$. deciduum and $20,645 \mathrm{kj} \mathrm{kg}^{-1}$ for E. tortuosum.

Twenty one species had heat combustion values above average: Acosmium dasycarpum, Aspidosperma macrocarpon, Aspidosperma tomentosum, Byrsonima coccolobaefolia, Byrsonima crassa, Byrsonima verbascifolia, Caryocar brasiliense, Connarus suberosus, Dalbergia miscolobium, Dimorphandra mollis, Erythroxylum tortuosum, Hymenaea stigonocarpa, Kielmeyera speciosa, Lafoensia pacari, Miconia ferruginata, Ouratea hexasperma, Pouteria ramiflora, Pterodon pubescens, Sclerolobium paniculatum, Stryphnodendron adstringens, Tabebuia serratifolia.

\subsection{Discussion.}

Species richness and density at this site was within the range found for several other cerrado sites (FELFILI and SILVA JUNIOR, 1993; FELFILI et al., 1997). This cerrado contained 12 of the 28 most common species for the biome listed by Ratter et al. (1996) being therefore, very representative of that vegetation.

The heat combustion with values between $18,903 \mathrm{kj}$ $\mathrm{kg}^{-1}$ and $20,888 \mathrm{kj} \mathrm{kg}^{-1}$ were similar or higher than those found for other tropical species such as Eriotheca globosa $\left(16,647 \mathrm{kj} \mathrm{kg}^{-1}\right)$, Ceiba samauma $\left(19,695 \mathrm{kj} \mathrm{kg}^{-1}\right)$ according to Meifa and Castilho (1992) and Acacia mangium (19,335 $\left.\mathrm{kj} \mathrm{kg}^{-1}\right)$ according to Vale et al. (1999). The 47 species studied here therefore presented a good potential for firewood and charcoal production. The species Dalbergia miscolobium, Pterodon pubescens and Sclerolobium paniculatum have potential for fuelwood managent in natural conditions and they could

\section{R. Árvore, Viçosa-MG, v.29, n.5, p.661-669, 2005}


also be cultivated, for having the best quality and higher biomass production. The slow growth of the aerial parts would lead to tree planting on degraded land where the deep root systems, which can be 20 times longer than the shoots and contain four times more biomass
(PAULILO and FELIPE, 1998), could help to improve the soils and contain erosion and also absorb carbon for a long time before reaching maturity. Planted in small rural properties they could bring a marginal income for the farmer.

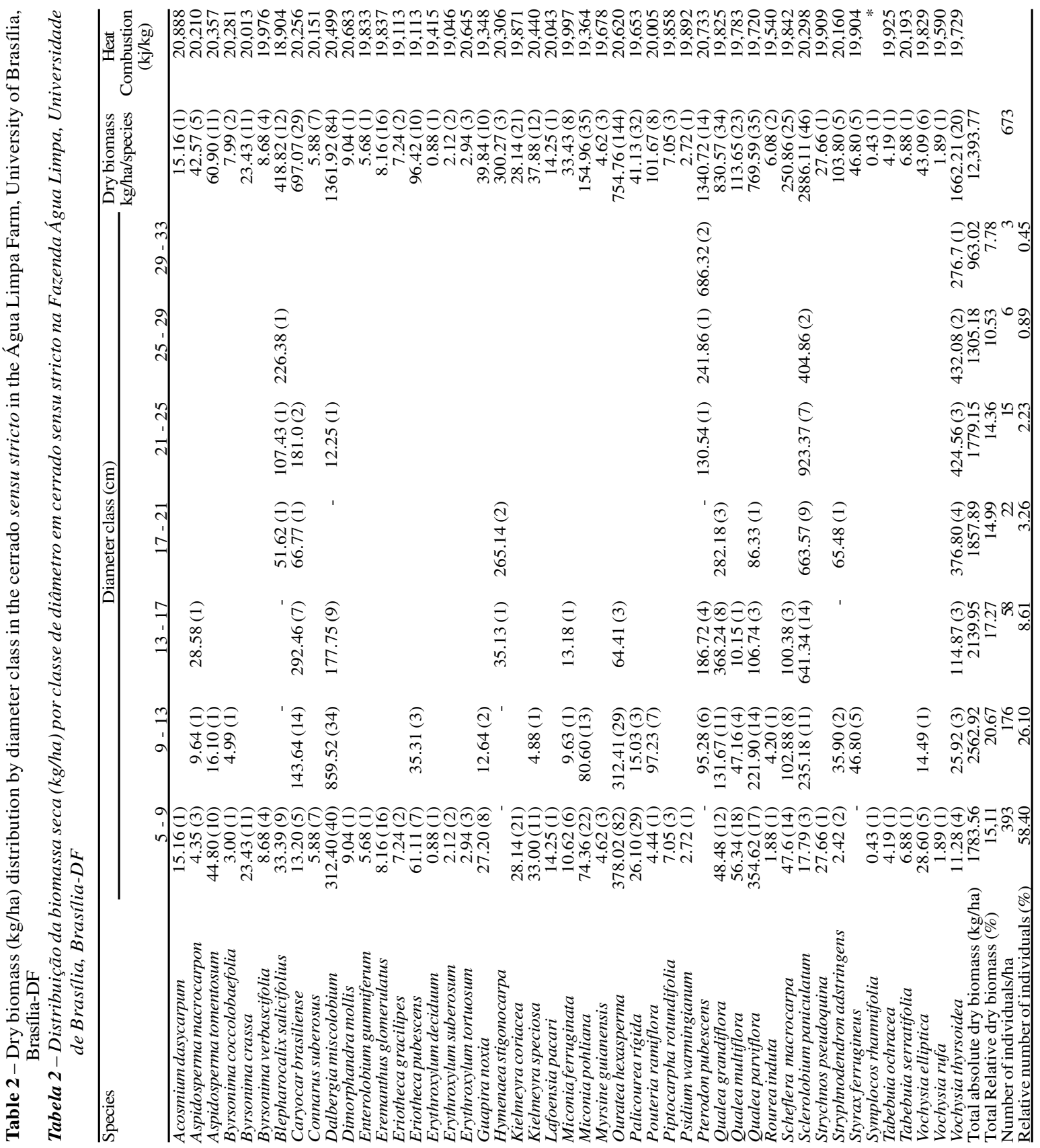

R. Árvore, Viçosa-MG, v.29, n.5, p.661-669, 2005 
Eighteen of the 21 species with SCP above average are widely distributed in the cerrado biome (RATTER et al. 1996), so fuelwood plantations with these species could help the conservation of these populations and management strategies developed for their management could be broadly used. These species were: Acosmium dasycarpum, Aspidosperma macrocarpon, Aspidosperma tomentosum, Byrsonima coccolobaefolia, Byrsonima crassa, Byrsonima verbascifolia, Caryocar brasiliense, Connarus suberosus, Dalbergia miscolobium, Dimorphandra mollis, Erythroxylum tortuosum, Hymenaea stigonocarpa, Lafoensia pacari, Ouratea hexasperma, Pouteria ramiflora, Pterodon pubescens, Sclerolobium paniculatum and Stryphnodendron adstringens.

Carbon sequestering in the cerrado sensu.strictu at the Água Limpa Farm was 6.2 ton/ha based on an average $50 \%$ carbon content in the dry matter. This content was distributed by diameter classes, reaching a maximum of 1.3 ton/ha between 13 to $17 \mathrm{~cm}$ and then, decreasing to 0.96 ton/ha between 29 to $33 \mathrm{~cm}$ diameter. The smaller diameter classes stock more carbon due to the large number of small plants per ha. But, for a species that reaches larger dimensions, Vochysia thyrsoidea and contained individuals in all diameter classes, one can verify an increase in carbon storage from $1.41 \mathrm{~kg} \mathrm{ha}^{-1}$ in the first class $(5$ to $9 \mathrm{~cm}$ ) to 482 $\mathrm{kg} \mathrm{ha}^{-1}$ in the last $(25$ to $33 \mathrm{~cm})$. That indicates a possibility to select species that reaches larger sizes with a higher capacity of carbon accumulation per plant.

The rapid sprouting of cerrado plants after fire and clear cutting are also positive features regarding carbon accumulation. These plants grow quicker than new seedlings since they usually have deep root systems. The larger quantity of carbon accumulation in the subterranean organs, roots and xylopodia (PAULILO and FELIPE, 1998) could also be an advantage of cerrado species under management for carbon accumulation. Stands could be cut, the aerial parts could be continuously growing after each cutting and at the same time most of the carbon accumulated would be kept underground.

\section{CONCLUSIONS}

The cerrado species studied here that presented high production per tree, high production per area and high hest combustion were Dalbergia miscolobium, Hymenaea stigonocarpa, Pterodon pubescens and

R. Árvore, Viçosa-MG, v.29, n.5, p.661-669, 2005
Sclerolobium paniculatum. These species, that reach larger sizes with a high capacity of carbon accumulation per plant, should be used in fuelwood plantations and be targeted for firewood management.

\section{ACKNOWLEDEGEMENTS}

We thank our sponsor, the CNPq-PELD, several people for field assistance and Mr Christopher William Fagg for kindly revising the manuscript.

\section{REFERENCES}

ASSOCIAÇÃO BRASILEIRO DE NORMAS

TÉCNICAS - ABNT - Norma NBR 8633.

Determinação do poder calorífico superior da madeira e do carvão vegetal. Rio de Janeiro: 1984.

BRASIL, Ministério das Minas e Energia. Balanço energético Nacional. Brasília: 2000. 154p.

BRITO, J.O. Madeira para energia: a verdadeira realidade do uso de recursos florestais. In:

CONGRESSO FLORESTAL

BRASILEIRO, 5., 1986, Recife. Anais. Recife: Sociedade Brasileira de Silvicultura, 1986. p.188-193.

DOAT, J. Le puovoir calorifique des bois tropicaux. Revue Bois et Forêts des Tropiques, v. 172, p. 33-48, 1977.

FELFILI, J.M.; SILVA JUNIOR, M.C. Distribuição dos diâmetros numa faixa de cerrado na Fazenda Água Limpa (FAL) em Brasília-DF. Acta

Botânica Brasílica, v.2, p.85-104, 1988.

FELFILI, J.M.; SILVA JR, M.C. A comparative study of cerrado (sensu stricto) vegetation in central Brazil. Journal of Tropical

Ecology, v.9, n.3, p.277-289, 1993.

FELFILI, J. M. et al. Projeto Biogeografia do Bioma Cerrado - Vegetação e Solos. Caderno de Geociências do IBGE, v.12, p.75-166, 1994.

FELFILI, J.M. Diversity, structure and dynamics of a gallery forest in central Brazil, Vegetatio, v.117, p.1-15, 1995. 
FELFILI, J.M. et al. Comparação Florística e Fitossociológica do Cerrado nas Chapadas Pratinha e dos Veadeiros. In: LEITE, L.; SAITO, C.H. Contribuição ao conhecimento ecológico do cerrado. Brasília: Universidade de Brasília, 1997. p.6-11

GRASSI, G.; PALZ, W. O futuro da biomassa na União Européia. Álcool \& Açúcar. v.76, p.28-34, 1988.

HARIDASAN, M. Nutrição mineral das plantas nativas do cerrado. Revista Brasileira de Fisiologia Vegetal, v. 12, n.1, p.54-64, 2000.

KRINGE, H.; ADIS, J.; WORBES, M. The vegetation of seasonal Várzea forest in the lower Solimões river, Brazilian Amazonia. Acta Amazônica, v.25, p.201-220, 1995.

MEIFA, M.N.E.; CASTILLO, M.U. Poder calorífico de cinco espécies de Bombacáceas. Revista Forestal del Peru, v.19, n.1, p.93-97, 1992.

MENDONÇA, R.C. et al. FLORA VASCULAR DO CERRADO. In: SANO, S.M.; ALMEIDA, S.P. Cerrado: ambiente e flora. Planaltina EMBRAPA - CERRADOS, 1998. p.289-556.

MITTERMEYER, R.A.; MYERS, N.; MITTERMEYER, C.G. Hotspots Earth's biologically richest and most endangered terrestrial ecoregions. New York: Conservation International, 1999. 430p.

NASCIMENTO, M.T.; SADDI, N. Structure and floristic composition in a $\mathrm{n}$ área of cerrado in Cuiabá-MT. Revista Brasileira de Botânica, v.15, n.1, p.47-55, 1992.

NIMER, E. Climatologia do Brasil. Rio de Janeiro, IBGE, 1989.
PAULILO, M.T.S.; FELIPE, G.M. Growth of the shrub-tree flora of the Brazilian cerrados: a review. Tropical Ecology, v.39, n.2, p.165-174, 1998.

PIRES, J. M. ; PRANCE, G.T. The Amazon forest: a natural heritage to be preserved. In: PRANCE, G.T.; ELIAS, E.S. (Eds.) Extinction is forever: Threatened and endangered species of plants in the Americas and their significance in ecosystems today and in the future. In: SYMPOSIUM HELD AT THE NEW YORK BOTANIC GARDEN. 1997, New York. Proceedings... New York: 1997. p.158-194.

RATTER, J.A. et al. Analysis of the floristic composition of the Brazilian cerrado vegetation II: Comparison of the wood vegetation of 98 areas. Edinburgh Journal of Botany, v.53, p.153-180, 1996.

RUGANI, C.A.; SCHLITTLER, F.H.M.; CARVALHO, J.B. Biomassa e estoque de nutrientes nos vários compartimentos de uma floresta secundária de terra firme em Manaus. Naturalia, v.22, p.103-113, 1997.

SILVA, F.C. Compartilhamento de nutrientes em diferentes componentes da biomassa aérea em espécies arbóreas de um cerrado. 1990. 80 f. Dissertação (Mestrado em Ecologia) Universidade de Brasília, Brasília, 1990.

SILVA JÚNIOR, M.C.; SILVA, A. F. Distribuição dos diâmetros dos troncos das espécies mais importantes do cerrado na Estação Experimental de Paraopeba (EFLEX-MG). Acta Botânica Brasílica, v.2, p.107-126, 1988.

VALE, A.T.; BRASIL, M.A.M.; MARTINS, I.S. Variação axial da densidade básica da madeira de Acacia mangium Willd aos sete anos de idade. Revista Ciencia Florestal, v.9, n.2, p.5-15, 1999. 